\title{
Viral polymerase inhibitors $T-705$ and $T-1105$ are potential inhibitors of Zika virus replication
}

\author{
Lei Cai ${ }^{1} \cdot$ Yajie Sun $^{1} \cdot$ Yabin Song $^{1} \cdot$ Likun $\mathrm{Xu}^{1} \cdot$ Zhuchun Bei $^{1}$ • \\ Dongna Zhang ${ }^{1} \cdot$ Yuanyuan Dou ${ }^{1} \cdot$ Hongquan Wang ${ }^{1}$
}

Received: 30 March 2017/ Accepted: 19 May 2017/Published online: 8 June 2017

(c) The Author(s) 2017. This article is an open access publication

\begin{abstract}
Since 2015, 69 countries and territories have reported evidence of vector-borne Zika virus (ZIKV) transmission. Currently, there are no effective licensed vaccines or drugs available for the treatment or prevention of ZIKV infection. We tested a series of compounds for their ability to inhibit ZIKV replication in cell culture. The compounds in T-705 (favipiravir) and T-1105 were found to have antiviral activity, suggesting that these compounds are promising candidates for further development as specific antiviral drugs against ZIKV.
\end{abstract}

Keywords Zika virus (ZIKV) · Broad-spectrum antiviral drugs $\cdot \mathrm{T}-705 \cdot \mathrm{T}-1105$

\section{Introduction}

Zika virus (ZIKV) is a member of the viral family Flaviviridae and the genus Flavivirus [1]. It is named after the Zika Forest of Uganda, where the virus was first isolated in 1947 [2]. ZIKV has reemerged in recent years, causing global outbreaks [3, 4]. In May 2015, a ZIKV outbreak was first reported in Brazil, and at least 69 countries and territories have since reported evidence of vector-borne ZIKV transmission [4]. The illness is usually mild, with

Electronic supplementary material The online version of this article (doi:10.1007/s00705-017-3436-8) contains supplementary material, which is available to authorized users.

Hongquan Wang

bjwanghq@163.com

1 State Key Laboratory of Pathogen and Biosecurity, Beijing Institute of Microbiology and Epidemiology, Academy of Military Medical Science, Beijing 100071, China symptoms lasting for several days [5]. However, there is now scientific consensus that ZIKV is linked to severe fetal malformations, serious disorders of the central nervous system [6, 7], and Guillain-Barré syndrome [4, 8], which has caused widespread concern. On February 1, 2016, the World Health Organization declared that the recent association of ZIKV infection with clusters of microcephaly and other neurological disorders constitutes a Public Health Emergency of International Concern. Therefore, increasing numbers of scientists are working on anti-ZIKV drugs or vaccines, and some progress has been made [9-11].

The development of highly effective, broad-spectrum antiviral agents is the major objective shared by the fields of virology and pharmaceutics. In this study, to identify a promising candidate drug to treat this disease, we evaluated ribavirin, CMX001 (brincidofovir), T-705 (favipiravir), and $\mathrm{T}-1105$ in cell culture to assess their ability to inhibit ZIKV infection. Ribavirin was first reported in 1972 as a broadspectrum antiviral drug that is active against a variety of RNA and DNA viruses in vitro and in vivo [12, 13]. CMX001 is an experimental antiviral agent infection for the treatment of cytomegalovirus, adenovirus, smallpox virus, and Ebola virus infections [14-16]. T-705, a nucleoside analogue that was first reported in 2002 [17], exerts potent broad-spectrum antiviral effects against many viruses, including influenza $\mathrm{A}$, $B$, and $C$ viruses [18, 19], human and avian viruses [12], and even Ebola virus (in 2014) [20]. This drug is also active against a wide variety of unrelated RNA viruses (reviewed by Furuta and coworkers) [21]. T-1105, a structural analogue of T-705, has been reported to exert broad-spectrum antiviral effects against some RNA virus, including foot-and-mouth disease virus and bovine viral diarrhea virus [21].

In the present study, the anti-ZIKV activity of a series of T-705 analogues substituted with several functional groups, including alkyl, ester, and aryl glycoside moieties, 
was evaluated. T-705 and T-1105 were found to have antiviral activity, suggesting that these two compounds are promising candidates for the further development of specific antiviral drugs against ZIKV.

A series of T-705 analogues (compounds 1-20) substituted with several functional groups, including alkyl, ester, and aryl glycoside moieties, were synthesized by the following methods (Fig. 1).

\section{4-ethyl-3-oxo-3,4-dihydropyrazine-2-carboxamide} (1)

T-1105 (1.39 g, $10.0 \mathrm{mmol})$ was dissolved in hexamethyldisilazane $(10 \mathrm{ml})$, heated to $130{ }^{\circ} \mathrm{C}$, and stirred for $6 \mathrm{~h}$. After it was cooled to room temperature and concentrated, dry acetonitrile $(15 \mathrm{ml})$ and ethyl chloride $(0.78 \mathrm{~g}, 12.1 \mathrm{mmol})$ were added, and the mixture was cooled to $0{ }^{\circ} \mathrm{C}$. Dry $\mathrm{SnCl}_{4}(1.2 \mathrm{ml}, 10.2 \mathrm{mmol})$ was added slowly, and the reaction mixture was then heated to room temperature and stirred for $5 \mathrm{~h}$. The reaction was terminated with saturated $\mathrm{NaHCO}_{3}$ solution, and the $\mathrm{pH}$ was adjusted to neutral before the solution was extracted with ethyl acetate. The organic phase was dried over $\mathrm{Na}_{2} \mathrm{SO}_{4}$, filtered, and concentrated to a sticky residue. The residue was purified by silica column chromatography to afford compound 1 (1.02 g, $6.1 \mathrm{mmol}$, $61.1 \%$ yield).

\section{2-((3-carbamoyl-2-oxopyrazin-1(2H)-yl) methoxy)} ethyl acetate (2)

Compound 2 was synthesized using a method similar to that described above for compound 1, with $23.8 \%$ yield.

\section{4-((2-hydroxyethoxy) methyl)-3-oxo-3,4- dihydropyrazine-2-carboxamide (3)}

Compound 2 (2.55 g, $10.0 \mathrm{mmol})$ was dissolved with $1 \mathrm{M}$ sodium methoxide $(1.8 \mathrm{ml})$ and stirred for $20 \mathrm{~min}$. The activated cation exchange resin ( $4 \mathrm{~g}$ ) was added, The suspension was was stirred for $30 \mathrm{~min}$, the $\mathrm{pH}$ was adjusted to neutral with dilute hydrochloric acid, and the sample was filtered. The solvent was evaporated to afford compound 3 (1.33 g, $5.2 \mathrm{mmol}, 62.4 \%$ yield)

\section{4-(2-hydroxy-3-(trityloxy) propyl)-3-oxo-3,4- dihydropyrazine-2-carboxamide (4)}

T1105 (1.39 g, $10.0 \mathrm{mmol})$ was dissolved in hexamethyldisilazane $(30 \mathrm{ml})$, heated to $130{ }^{\circ} \mathrm{C}$, and stirred for $6 \mathrm{~h}$. After it was cooled to room temperature and concentrated, dry dimethylformamide $(60 \mathrm{ml}), \quad \mathrm{s}-(-)-2-(($ trityloxy $)$ methyl) oxirane $(10.01 \mathrm{~g}, 32.2 \mathrm{mmol})$, and $\mathrm{K}_{2} \mathrm{CO}_{3}(0.82 \mathrm{~g}$, $5.9 \mathrm{mmol})$ were added, and the reaction mixture was stirred

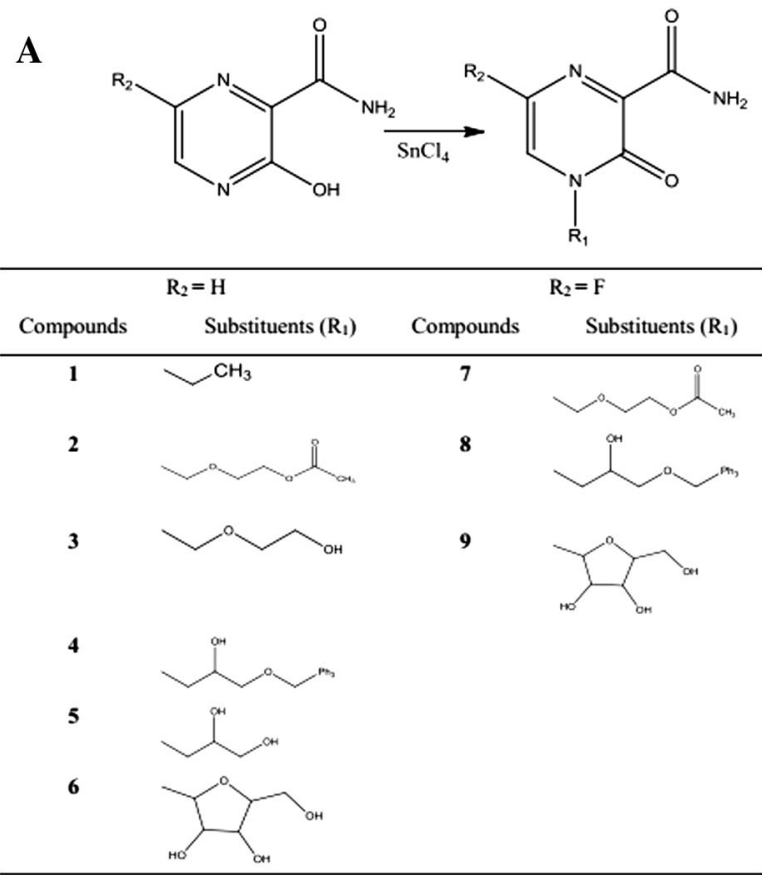

B
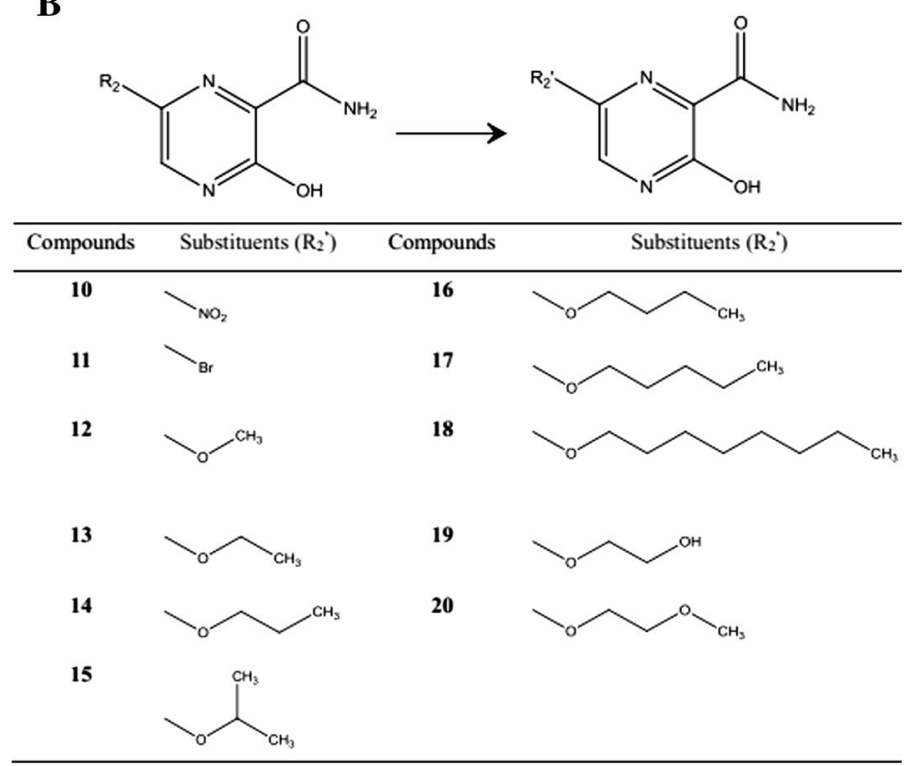

Fig. 1 The synthetic route to the target compounds A. compounds (1-9). B. compounds 10-20 
at $90{ }^{\circ} \mathrm{C}$ for $40 \mathrm{~h}$. The reaction was terminated with water $(70 \mathrm{ml})$ and the material was extracted with ethyl acetate. The organic phase was collected and dried over $\mathrm{NaSO}_{4}$, filtered, and concentrated to a sticky residue. The residue was purified by silica column chromatography to afford 4 (3.24 g, $7.1 \mathrm{mmol}, 22.4 \%$ yield).

\section{4-(2,3-dihydroxypropyl)-3-oxo-3,4- dihydropyrazine-2-carboxamide $(5)$}

Compound 4 (2.02 g, $4.5 \mathrm{mmol})$ was dissolved in $80 \%$ $\mathrm{HCOOH}(20 \mathrm{ml})$ and stirred at room temperature for 30 min. The reaction mixture was extracted with water and dichloromethane. The aqueous phase was collected and concentrated to give a sticky residue. The product was isolated by silica gel column chromatography and dried to give compound 5 (0.54 g, $2.25 \mathrm{mmol}, 53.3 \%$ yield).

\section{4-(3,4-dihydroxy-5- (hydroxymethyl)tetrahydrofuran-2-yl)-3-oxo-3,4- dihydropyrazine-2-carboxamide (6)}

T-1105 (7.01 g, $50.4 \mathrm{mmol}$ ) was dissolved in hexamethyldisilazane $(50 \mathrm{ml})$, heated to $130{ }^{\circ} \mathrm{C}$, and stirred for 6 h. After it was cooled to room temperature and concentrated, tetraacetyl ribose $(3.90 \mathrm{~g}, 12.2 \mathrm{mmol})$ was dissolved in acetonitrile $(75 \mathrm{ml})$, and the mixture was cooled to $0{ }^{\circ} \mathrm{C}$. Dry $\mathrm{SnCl}_{4}(5.75 \mathrm{ml}, 49.1 \mathrm{mmol})$ was added slowly dropwise and the mixture was stirred at room temperature overnight. The reaction was terminated with saturated $\mathrm{NaHCO}_{3}$ solution, the $\mathrm{pH}$ was adjusted to neutral, and the solution was extracted with ethyl acetate. The organic phase was dried over $\mathrm{Na}_{2} \mathrm{SO}_{4}$, filtered, and concentrated to a sticky residue. The product was isolated on a silica gel column and dried to give intermediate $(5.45 \mathrm{~g}, 13.7 \mathrm{mmol})$. The intermediate $(5.45 \mathrm{~g}, 13.7 \mathrm{mmol})$ was dissolved in methyl alcohol $(60 \mathrm{ml})$, and the mixture was cooled to $0{ }^{\circ} \mathrm{C} .5 \mathrm{M}$ sodium methoxide $(6.11 \mathrm{~g})$ was added, and the mixture was stirred for $30 \mathrm{~min}$. The $\mathrm{pH}$ was adjusted to neutral with acetic acid, and the material was filtered and concentrated to a sticky residue. The residue was purified by silica column chromatography to afford 6 (1.36 g, 5.0 mmol, $50.2 \%$ yield).

\section{2-((3-carbamoyl-5-fluoro-2-oxopyrazin-1(2H)-yl) methoxy) ethyl acetate (7)}

Compound 7 was synthesized using a method similar to that described above for compound 2, with $19.6 \%$ yield. 6-fluoro-4-(2-hydroxy-3-(trityloxy)propyl)-3-oxo3,4-dihydropyrazine-2-carboxamide (8)

Compound 8 was synthesized using a method similar to that described above for compound 4 , with $16.3 \%$ yield.

4-(3,4-dihydroxy-5(hydroxymethyl)tetrahydrofuran-2-yl)-6-fluoro-3oxo-3,4-dihydropyrazine-2-carboxamide (9)

Compound 9 was synthesized using a method similar to that described above for compound 6, with $69.9 \%$ yield.

\section{6-nitropyrazine-3-hydroxy-2-carboxamide (10)}

T-705 (1.57 g, $10.0 \mathrm{mmol}$ ) was dissolved in $60 \%$ nitric acid $(9 \mathrm{ml})$ and cooled to $0{ }^{\circ} \mathrm{C}$. $\mathrm{SOCl}_{2}(1.2 \mathrm{ml}, 16.9$ mmol) was added slowly and stirred at room temperature for $2 \mathrm{~h}$. The material was stored at $4{ }^{\circ} \mathrm{C}$ overnight and filtered to afford compound $10(1.23 \mathrm{~g}, 6.7 \mathrm{mmol}, 66.8 \%$ yield).

\section{6-bromo-3-hydroxypyrazine-2-carboxamide (11)}

T-1105 (1.51 g, $10.8 \mathrm{mmol})$ and pyridine $(1.5 \mathrm{ml})$ were added to dimethylformamide $(4 \mathrm{ml})$ to form an emulsion. The reaction was heated to $80^{\circ} \mathrm{C}$ and liquid bromine $(0.7 \mathrm{ml}, 13.7 \mathrm{mmol})$ was added slowly. The reaction mixture was stirred at room temperature for $2 \mathrm{~h}$, and the reaction was terminated with water $(6 \mathrm{ml})$, cooled, and filtered. Then, the filter cake was washed with a small amount of water to afford compound $11(1.15 \mathrm{~g}, 5.3 \mathrm{mmol}$, $48.8 \%$ yield).

\section{3-hydroxy-6-methoxypyrazine-2-carboxamide (12)}

T-705 (1.57 g, $10.0 \mathrm{mmol})$ was dissolved in methyl alcohol $(5 \mathrm{ml}, 64.5 \mathrm{mmol}) . \mathrm{SOCl}_{2}(1.2 \mathrm{ml}, 16.9 \mathrm{mmol})$ was added slowly, and the mixture was heated to $40{ }^{\circ} \mathrm{C}$ and stirred for $2 \mathrm{~h}$. It was then cooled to room temperature and filtered to afford compound $12(0.98 \mathrm{~g}, 5.8$ mmol, $57.9 \%$ yield).

\section{6-ethoxy-3-hydroxypyrazine-2-carboxamide (13)}

Compound 13 was synthesized using a method similar to that described above for compound 12 , with $68.8 \%$ yield. 


\section{3-hydroxy-6-propoxypyrazine-2-carboxamide (14)}

Compound 14 was synthesized using a method similar to that described above for compound 12 , with $77.2 \%$ yield.

\section{6-isopropoxypyrazine-3-hydroxy-2-carboxamide} (15)

Compound 15 was synthesized using a method similar to that described above for compound12, with $68.0 \%$ yield.

\section{6-butoxy-3-hydroxypyrazine-2-carboxamide (16)}

Compound 16 was synthesized using a method similar to that described above for compound 12, with $59.2 \%$ yield.

\section{3-hydroxy-6-(pentyloxy)pyrazine-2-carboxamide (17)}

Compound 17 was synthesized using a method similar to that described above for compound12, with $68.4 \%$ yield.

\section{3-hydroxy-6-(octyloxy)pyrazine-2-carboxamide (18)}

Compound 18 was synthesized using a method similar to that described above for compound 12, with $74.1 \%$ yield.

\section{3-hydroxy-6-(2-hydroxyethoxy) pyrazine-2- carboxamide (19)}

Compound 19 was synthesized using a method similar to that described above for compound 12 , with $76.8 \%$ yield.

\section{3-hydroxy-6-(2-methoxyethoxy) pyrazine-2- carboxamide (20)}

Compound 20 was synthesized using a method similar to that described above for compound 12, with $64.3 \%$ yield.

We tested a series of compounds for their ability to inhibit ZIKV replication in cell culture. In this study, Vero cells were incubated at $37{ }^{\circ} \mathrm{C}$ in Dulbecco's modified Eagle medium (HyClone) with 10\% fetal bovine serum (Gibco) [22]. The ZIKV strain SZ01 (GenBank accession number KU866423.2) was used in the experiment. It was isolated from a Chinese patient who had returned from Samoa in 2016, and it belongs to the Asian lineage [23].
For cell culture experiments, ribavirin, CMX001, T-705 and T-1105 (all $>95 \%$ purity) were initially dissolved in $100 \%$ dimethyl sulfoxide (DMSO). The compounds were then diluted to the desired concentrations in $1 \%$ DMSO.

The Spearman-Karber method was used to determine the ZIKV stock titers [24]. Briefly, Vero cells (approximately $3 \times 10^{4}$ cells/well) were seeded in the wells of a 96-well plate and incubated at $37^{\circ} \mathrm{C}$ under an atmosphere of $5 \% \mathrm{CO}_{2}$ for $24 \mathrm{~h}$ before infection. The cells were infected with serial dilutions of the virus from $10^{-1}$ to $10^{-10}(100 \mu \mathrm{l} /$ well $)$, incubated at $37^{\circ} \mathrm{C}$, and monitored for any cytopathic effect (CPE). The viral titer was calculated using the Spearman-Karber formula, and the results are presented as the half-maximal (50\%) tissue culture infective dose $\left(\mathrm{TCID}_{50}\right)$.

The cytotoxicity of the compounds against Vero cells was determined by monitoring the CPE. Vero cells $\left(2.5 \times 10^{4} /\right.$ well $)$ were plated in the wells of a 96-well plate. After $24 \mathrm{~h}$, the cell monolayer was incubated with different concentrations of the test compounds for $72 \mathrm{~h}$ at $37{ }^{\circ} \mathrm{C}$ under a $5 \% \mathrm{CO}_{2}$ atmosphere in a $\mathrm{CO}_{2}$ incubator and then monitored for CPE. The appropriate negative and positive controls were used. A neutral red uptake assay [25] was used to assess cell viability. The half-maximal (50\%) cytotoxic concentration $\left(\mathrm{CC}_{50}\right)$ of each compound was determined from the dose-response curve.

The anti-ZIKV activities of the compounds were evaluated in Vero cells using a CPE inhibition assay [22]. Confluent Vero cells grown in 96-well microplates were infected with $68.6 \mathrm{TCID}_{50}$ of the test strain and then treated with fivefold serial dilutions of the test compounds. Incubation with each concentration was performed in triplicate. The vehicle, $1 \%$ DMSO (final concentration), was used as the negative control. The CPE was monitored until it reached a level 4 in the cells of the control group. The neutral red uptake assay was used to assess cell viability. The half-maximal $(50 \%)$ effective concentration $\left(\mathrm{EC}_{50}\right)$ of each compound was determined from the dose-response curve.

This study was designed to improve the activity of the drug T-705, reduce its organ-targeting toxicity, and develop a new candidate treatment for ZIKV infection. $\mathrm{T}-705$ has a simple structure, and we engineered changes at two positions. As shown in Fig. 1, the chemical structures of the target analogues included changes to the substituents on the pyrazine at two positions, 4 and 6 . We selected 3-hydroxypyrazine-2-carboxamide as the lead compound, and 20 compounds were synthesized with structural modifications by introducing functional groups at the 4 and 6 positions, including alkyl, ester, and sugar moieties.

We evaluated the anti-ZIKV activities of these compounds against ZIKV strain SZ01 in Vero cells. The synthetic compounds had weak or no antiviral activity in the 
concentration range of $200-600 \mu \mathrm{M}$. Ribavirin was not active at concentrations below $400 \mu \mathrm{M}$, and CMX001 was not active at concentrations below $18 \mu \mathrm{M}$. As shown in Table 1, ribavirin and CMX001 had little or no effect on ZIKV-induced CPE or cell death. However, T-705 and $\mathrm{T}-1105$ significantly reduced the cell death rate in the test wells compared with that in the mock-treated ZIKV-infected cells $(P<0.05$, two-tailed Student's $t$-test $)$. The $\mathrm{EC}_{50}$ of T-705 was $110.9 \pm 13.1 \mu \mathrm{M}$ and that of $\mathrm{T}-1105$ was $97.5 \pm 6.8 \mu \mathrm{M}$. The dose-response curve results are shown in Fig. 2.

The continuation of outbreaks of ZIKV infection in Southeast Asia and the Americas emphasizes the urgent need for effective antiviral drugs. Many scientists have been working on anti-ZIKV drugs [10, 11, 26, 27], including D. Růžek and co-workers [26], who suggested that 2'-C-methylated nucleosides might be promising candidates for the development of specific antiviral drugs against ZIKV. In this study, we found that T-705 and T-1105 effectively inhibited ZIKV in vitro.

Table 1 Antiviral activity of compounds against ZIKV strain SZ01

\begin{tabular}{|c|c|c|}
\hline Compound & $\mathrm{CC}_{50}(\mu \mathrm{M})$ & $\mathrm{EC}_{50}(\mu \mathrm{M})$ \\
\hline Ribavirin & $>2000$ & NA \\
\hline CMX001 & $11.3 \pm 0.2$ & NA \\
\hline $\mathrm{T}-705$ & $>3000$ & $110.9 \pm 13.1$ \\
\hline $\mathrm{T}-1105$ & $>4000$ & $97.5 \pm 6.8$ \\
\hline 1 & $>1000$ & $\mathrm{NA}$ \\
\hline 2 & $>2000$ & NA \\
\hline 3 & $>1000$ & NA \\
\hline 4 & $>500$ & NA \\
\hline 5 & $>2000$ & NA \\
\hline 6 & $>1000$ & NA \\
\hline 7 & $>1000$ & NA \\
\hline 8 & $>500$ & NA \\
\hline 9 & $>1000$ & NA \\
\hline 10 & $>4000$ & NA \\
\hline 11 & $>2000$ & NA \\
\hline 12 & $>1000$ & NA \\
\hline 13 & $>500$ & NA \\
\hline 14 & $>500$ & NA \\
\hline 15 & $345.4 \pm 48.4$ & NA \\
\hline 16 & $309.5 \pm 15.2$ & NA \\
\hline 17 & $259.9 \pm 51.1$ & NA \\
\hline 18 & $245.4 \pm 17.8$ & NA \\
\hline 19 & $>1000$ & NA \\
\hline 20 & $>1000$ & NA \\
\hline
\end{tabular}

Determined from three independent experiments

$\mathrm{CC}_{50}, 50 \%$ cytotoxic concentration; $\mathrm{EC}_{50}, 50 \%$ effective concentration; SD, standard deviation, NA, not applicable

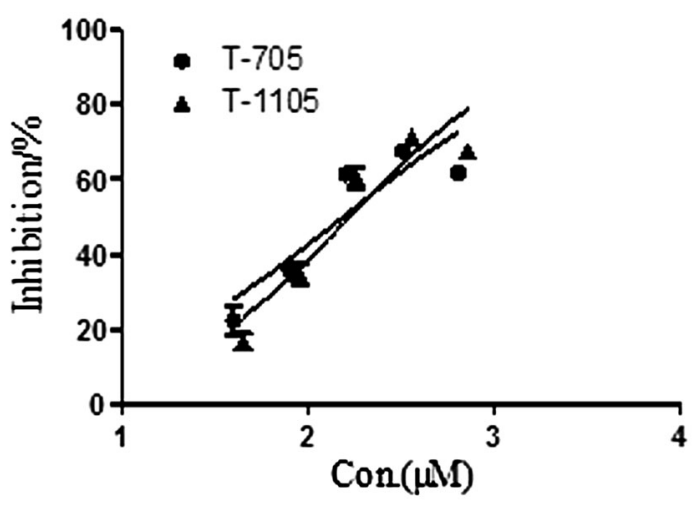

Fig. 2 Dose-response curves showing the in vitro antiviral activity of T-705 and T-1105 against ZIKV strain SZ01. Prism 5.0 software was used to plot the data from parallel experiments

ZIKV, like other flaviviruses, is an enveloped, singlestranded positive-sense RNA virus [28]. It has been hypothesized that ZIKV uses the RNA-dependent RNA polymerase (RdRp or the non-structural protein, NS5), together with cofactors to replicate, maintain its infection, and express its RNA genome [26-28]. T-705 is converted to the active form, ribofuranosyl triphosphate (T-705-RTP), by host cell enzymes and selectively inhibits the activity of the influenza viral RNA polymerase [15]. T-705 also inhibits several pathogenic flaviviruses, including yellow fever virus (YFV) and West Nile virus (WNV) [29, 30], which prompted the hypothesis that T-705 inhibits the polymerases of YFV and WNV. Therefore, we suggest that T-705 also acts by inhibiting the RNA polymerase of ZIKV.

A series of derivatives of T-705 were tested, and these compounds had little or no effect on ZIKV-induced CPE or cell death. Several functional groups, including alkyl, ester, and sugar moieties, were introduced into compounds $1-9$ at the 4-N position. Compounds 6 and 9 are the ribosides of $\mathrm{T}-1105$ and T-705, respectively. These modified molecules did not inhibit the replication of ZIKV, and we suggest two possible mechanisms to explain this failure. One possible explanation is that the side chains of the substituents altered the oil/water partition coefficients, which may have changed the cell permeability of the compounds. Another explanation may be that the effective concentrations were higher than the test concentrations. As reported by Furuta et al., compound 6 was effective in a hamster model of YFV infection, although it was previously shown to have only slight activity at low concentrations in cell culture [28]. In a future study, we will test the antiviral activities of these compounds at higher concentrations and in vivo to identify other effective compounds for the treatment of ZIKV disease. In compounds 10-20, the $-\mathrm{F}$ moiety was substituted with other groups, including nitro and ether groups. These side chains may have changed the charge distribution on the molecules or caused greater steric 
hindrance effects than $\mathrm{F}$ and $\mathrm{H}$. Therefore, the derivatives of T-705 do not act like T-705-RTP in inhibiting the viral RNA polymerase in host cells.

In conclusion, we have demonstrated that the derivatives of T-705 had little or no effect at the tested concentrations (about 200-600 $\mu \mathrm{M}$ ). However, T-705 and T-1105 displayed anti-ZIKV activity in vitro. In a future study, we will test the antiviral activities of the substituted compounds at higher concentrations and undertake in vivo experiments to identify other effective compounds for the treatment of ZIKV disease.

Acknowledgements The authors are grateful to the Department of Virology, Beijing Institute of Microbiology and Epidemiology, for providing the virus isolates used in this study.

\section{Compliance with ethical standards}

Funding This work was supported by the National Science and Technology Major Project, China, Grant Number 2015ZX09102022.

Conflict of interest The authors declare that there are no conflicts of interest.

Ethical approval This article does not contain any studies with animals performed by any of the authors.

Informed consent Informed consent was obtained from all individual participants included in the study.

Open Access This article is distributed under the terms of the Creative Commons Attribution 4.0 International License (http://creative commons.org/licenses/by/4.0/), which permits unrestricted use, distribution, and reproduction in any medium, provided you give appropriate credit to the original author(s) and the source, provide a link to the Creative Commons license, and indicate if changes were made.

\section{References}

1. Lanciotti RS, Kosoy OL, Laven JJ, Velez JO, Lambert AJ et al (2008) Genetic and serologic properties of Zika virus associated with an epidemic, Yap State, Micronesia, 2007. Emerg Infect Dis 14:1232-1239

2. Dick GW, Kitchen SF, Haddow AJ (1952) Zika virus. I. Isolations and serological specificity. Trans R Soc Trop Med Hyg 46:509-520

3. Roth A, Mercier A, Lepers C, Hoy D, Duituturaga S et al (2014) Concurrent outbreaks of dengue, chikungunya and Zika virus infections - an unprecedented epidemic wave of mosquito-borne viruses in the Pacific 2012-2014. Eurosurveillance 19:2-9

4. World Health Organization, Zika situation report (2017) http:// www.who.int/emergencies/zika-virus/situation-report/05-jan uary-2017/en/. Accessed 17 Jan 22

5. Malone RW, Homan J, Callahan MV, Glasspool-Malone J, Damodaran L et al (2016) Zika virus: medical countermeasure development challenges. PLoS Negl Trop Dis 10:e0004530

6. Faizan MI, Abdullah M, Ali S, Naqvi IH, Ahmed A et al (2017) Zika virus-induced microcephaly and its possible molecular mechanism. Intervirology 59:152-158
7. Schuler-Faccini L, Ribeiro EM, Feitosa IML, Horovitz DDG, Cavalcanti DP et al (2016) Possible association between Zika virus infection and microcephaly-Brazil, 2015. MMWR 65:59-62

8. Oehler E, Watrin L, Larre P, Leparc-Goffart I, Lastère S, Valour F, Baudouin L, Mallet H, Musso D, Ghawche F (2014) Zika virus infection complicated by Guillain-Barré syndrome-case report, French Polynesia. Euro Surveill 19:3

9. Dowd KA, Ko SY, Morabito KM, Yang ES, Pelc RS et al (2016) Rapid development of a DNA vaccine for Zika virus. Science 354:237-240

10. Hercik K, Kozak J, Sala M, Dejmek M, Hrebabecky H et al (2017) Adenosine triphosphate analogs can efficiently inhibit the Zika virus RNA-dependent RNA polymerase. Antiviral Res 137:131-133

11. Coutard B, Barral K, Lichière J, Selisko B, Martin B et al (2017) Zika virus methyltransferase: structure and functions for drug design perspectives. J Virol 91. doi:10.1128/JVI.02202-16

12. Sidwell RW, Barnard DL, Day CW, Smee DF, Bailey KW et al (2007) Efficacy of orally administered T-705 on lethal avian influenza A (H5N1) virus infections in mice. Antimicrob Agents Chemother 51:845-851

13. Crotty S, Maag D, Arnold JJ, Zhong W, Lau JY et al (2000) The broad-spectrum antiviral ribonucleoside ribavirin is an RNA virus mutagen. Nat Med 6:1375-1379

14. Quenelle DC, Lampert B, Collins DJ, Rice TL, Painter GR et al (2010) Efficacy of CMX001 against herpes simplex virus infections in mice and correlations with drug distribution studies. J Infect Dis 202:1492-1499

15. Florescu DF, Keck MA (2014) Development of CMX001 (Brincidofovir) for the treatment of serious diseases or conditions caused by dsDNA viruses. Expert Rev Anti Infect Ther 12:1171-1178

16. Florescu DF, Kalil AC, Hewlett AL, Schuh AJ, Stroher U et al (2015) Administration of brincidofovir and convalescent plasma in a patient with ebola virus disease. Clin Infect Dis 61:969-973

17. Furuta Y, Takahashi K, Fukuda Y, Kuno M, Kamiyama T et al (2002) In vitro and in vivo activities of anti-influenza virus compound T-705. Antimicrob Agents Chemother 46:977-981

18. Furuta Y, Takahashi K, Kuno-Maekawa M, Sangawa H, Uehara S et al (2005) Mechanism of action of T-705 against influenza virus. Antimicrob Agents Chemother 49:981-986

19. Sleeman K, Mishin VP, Deyde VM, Furuta Y, Klimov AI et al (2010) In vitro antiviral activity of favipiravir (T-705) against drug-resistant influenza and 2009 A(H1N1) viruses. Antimicrob Agents Chemother 54:2517-2524

20. Oestereich L, Ludtke A, Wurr S, Rieger T, Munoz-Fontela C et al (2014) Successful treatment of advanced Ebola virus infection with T-705 (favipiravir) in a small animal model. Antiviral Res 105:17-21

21. Furuta Y, Gowen BB, Takahashi K, Shiraki K, Smee DF et al (2013) Favipiravir (T-705), a novel viral RNA polymerase inhibitor. Antiviral Res 100:446-454

22. Deng YQ, Zhang NN, Li CF, Tian M, Hao JN et al (2016) Adenosine analog NITD008 is a potent inhibitor of Zika virus. Open Forum Infect Dis 3:ofw175

23. Deng YQ, Zhao H, Li XF, Zhang NN, Liu ZY et al (2016) Isolation, identification and genomic characterization of the Asian lineage Zika virus imported to China. Sci China Life Sci 59:428-430

24. Cann AJ (1999) Virus culture: a practical approach. Oxford University Press, Oxford, pp 83-84

25. Repetto G, del Peso A, Zurita JL (2008) Neutral red uptake assay for the estimation of cell viability/cytotoxicity. Nat Protoc 3:1125-1131 
26. Eyer L, Nencka R, Huvarova I, Palus M, Joao Alves M et al (2016) Nucleoside inhibitors of Zika virus. J Infect Dis 214:707-711

27. Hercik K, Brynda J, Nencka R, Boura E (2017) Structural basis of Zika virus methyltransferase inhibition by sinefungin. Arch Virol. doi:10.1007/s00705-017-3345-x

28. Cox BD, Stanton RA, Schinazi RF (2015) Predicting Zika virus structural biology: challenges and opportunities for intervention. Antivir Chem Chemother 24:118-126
29. Julander JG, Shafer K, Smee DF, Morrey JD, Furuta Y (2009) Activity of T-705 in a hamster model of yellow fever virus infection in comparison with that of a chemically related compound, T-1106. Antimicrob Agents Chemother 53:202-209

30. Morrey JD, Taro BS, Siddharthan V, Wang H, Smee DF et al (2008) Efficacy of orally administered T-705 pyrazine analog on lethal West Nile virus infection in rodents. Antiviral Res 80:377-379 